Nada Soudi,

Professor, Business School ISCAE, Morocco

\title{
IT KNOWLEDGE MANAGEMENT: EXTENDING PRINCIPALS OF CSR
}

\begin{abstract}
Corporate social responsibility is no more a luxury but a must that will ensure the inclusion of the population and the sustainability of resources. It is a voluntaries integration by companies of social and environmental concerns into their strategy and their stakeholder's relations. This paper, through the literature review, allows, as a first step, to find similarities in each decade of CSR definitions and to highlight how theorists evolve in defining the concept. The objective of the research is to identify the gap in developing countries, by ranking companies according to their CSR perception, and how they link this discipline to doing business. The purpose is to highlight the decennial gap, mainly when CSR is defined more as philanthropies acts, without any coercive system that strives for companies to comply with CSR values. The problems can be summarised in the following question: Is CSR having the same perception in developing countries? If there is a hole, how many years represent this gap according to different segments of companies? The paper presents the result of empirical analysis relied into qualitative study that targeted the companies from different sizes. The random sample is complicated to apply since the proportion of SMBs is very high, and therefore the results can be biased and cannot be generalised. Thus, the choice is about convenience sample of a total of 80 companies surveyed regarding awareness of CSR as a concept, Kind of applied purposes, CSR motivations, CSR brakes and CSR perspectives. The use of IT knowledge management allows us to find similarities between these perceptions and different categories of companies. As the first conclusion, a reverted triangle confirms that the small and tiny companies, still have the 70's perception of CSR, as a voluntaries commitment, and they represent the most significant proportion of firms. At the opposite, large companies and Moroccan subcontractor companies, that represent deficient proportion (5\%) perceive CSR as an imperative of survival and are in the same trend as the global vision of CSR. So, as an answer of the problematic, the perception is not the same for the small companies but tend to be the same as the international perception once they are larger or they are doing business with the international market. The results of this research can be useful for abroad companies that need to know about the Moroccan vision of CSR, or for sensibilization of local companies regarding the gap that needs to fill in.
\end{abstract}

Keywords: CSR, developing countries, evolution, IT knowledge management.

Introduction. CSR is considered a multidisciplinary concept that is continuously evolving, in terms of definitions, chronological evolution of core concept, and regulatory standards referring to this discipline. State of the art allows finding, in each decade, some similarities in definitions. In the 60s', CSR was more perceived as voluntarism, in '70s as collective commitment, in the ' 80 s, CSR was analysed in terms of impact and performance, and since 2000, CSR is an imperative of survival. This fundamental evolution influenced the regulatory standards that evolve as well to assess the CSR activities better. Nevertheless, the CSR perception, in theory, cannot be the same on the ground, especially in developing countries. The purpose of the article is to highlight the gap between the theoretical and operational approaches by answering the following problematic: Is CSR having the same perception in developing countries? If there is a hole, how many years represent this gap according to different segments of companies?

Literature Review. Although the definitions are multiple, the most commonly used are: CSR is defined as «the willing integration of social and environmental concerns into business activities and collaborations with other parties». Firms are more conscious that a reputable business is translated into sustainable business success. According to the «International Organization for Standardization» (ISO), CSR is: "the responsibility of an organisation according to the impacts of its decisions and activities on society and the environment, translated into ethical and transparent commitment, including environment, health and wellbeing of society and stakeholders».

According to «Business for Social Responsibility» (BSR), the CSR is a business practice that «reforms responsibilities and reverts ethical values for the benefit of all stakeholders». The BSR also offers the

Cite as: Soudi, N. (2020). IT Knowledge Management: Extending Principals of CSR. Marketing and Management 192 
opportunity to take advantage of the local business opportunities to experience the current environment and to help improve the quality of business and leisure opportunities. Reputable business practices give people the power to continue doing business. It is excellent disposal that gives them the confidence to stay in the entrepreneurship community.

According to the «World Business Council for Sustainable Development» (WBCSD), CSR is integrated into a sustainable development context. In the WBCSD, the CSR is the continuous commitment of people to act ethically and contribute to economic development, while improving the quality of employee's life, and people in society.

All the definitions state that the concept of sustainable development is a pursuit of learning through the evaluation of social, environmental and economic performance.

Berle and Means (1937) from Harvard University highlighted the CSR concept. In the book «The Modern Corporation and Private Property», they struggle for maintaining ownership rights, transparency and greater responsibility in large organisations. These underlying values are the same as the current CSR definition but without formalisation. Also, according to the concept of «private property» in a public place, the Wall Street crash in 1929, showed the lack of responsibility of owners. In the literature, the official CSR articles were featured for the first time in Bowen's book (1953) entitled «Social Responsibilities of the Business Man». It defines the CSR as follows: «The obligations of businessmen to pursue these policies, make these decisions or follow up on these lines of action that are desirable to reach objectives following values of the company». Bowen was convinced that the business contributes to social benefits such as: raising the level of life; generalisation of economic progress and security; justice and liberty; and citizen's development. That is why he perceived CSR as a social obligation with a more exceptional ability than the most straightforward commercial responsibilities. According to him, the CSR understands social receptiveness and improve citizenship.

In the 1960s, there was a formalisation of the CSR as an act of voluntarism. Davis (1960) suggests that «social responsibility refers to the decision reasons that go beyond, at least in social part, to serve the economic and technical interests of the industry». His "Law of fame Responsibility» underscores the importance of «social values» and the «power of social companies» that Bowen (1953) and Berle and Means (1932) had defined. Frederick (1960) defines CSR as the use of the company's resources; economic and human, to have the maximum of advantages beyond the moral and personal interests of their owners. Walton (1967) in his book "Corporate Social Responsibility», emphasised on the notion of «voluntarism». He believes that CSR always has a high degree of volunteerism since there is no measurable financial performance. Friedman (1962) was against the doctrine of CSR, which he described as «fundamentally subversive». His position has been intensely criticised.

In the 1970s, authors focused on the company's commitment and «the licence to operate». Harold Johnson (1971), in his book entitled «Business in contemporary society», testifies that «A socially responsible company is a company where employees and managers have multiple interests instead of being focused only on obtaining greater profits for shareholders». The "Committee for Economic Development CED» (1971), developed a triple steps model. The CSR concept includes the fundamental responsibilities that are bringing financial performance, such as productivity, employment, economic growth, which reflect the notion of "commercial responsibility» of Friedman (1962). The second layer is referring to the responsibility regarding the evolution of values and social priorities, such as environment, relationship with employees, and consumer information. The last step describes the new responsibilities that the company should embrace in order to become more involved in the ongoing improvement of the social environment. Carroll (1979) described the CED model as «a major contribution to the CSR Concept», that illustrates the evolution of the link company- Social environment. She added: «We are looking for companies to take on greater responsibility than ever before referring to human values». They are contributing to the quality of life rather than supplying goods and services. Fredrick (1978) notified that the CSR paradigm shifted from 
«philosophical and moral obligation» to «managerial and organisational action». While the first is reactive, impulsed by the economic and social concerns, the second is proactive and anticipatory, aimed to influence and modify the environment for better performance.

Eells and Walton (1974) have adopted a more comprehensive vision of entrepreneurship that could foster «The licence to operate». They suggested that a senior executive must be grounded in his philosophy, has an open attitude to take decisive action immediately reachable and compatible with the values of the company. Sethi (1975) proposed a three-tiered model that classifies the behaviour in terms of increasing levels of engagement. The first behaviour is related to the social obligation (a response to legal and commercial constraints), second is the social responsibility (following the principles of social responsibility and social norms), and the last is social responsiveness (adaptability and anticipation).

From this point of view, social responsibility goes beyond the social obligation and understands the need of society to improve the behaviour of people following social norms, values, and performance oriented.

In the 1980s, the authors were interested in the measure of CSR impact. Jones (1980) defined CSR as a collaboration between citizens and companies rather than only companies' shareholders. It is working beyond the scope of the law and the collective convocation. Tuzzolino and Armandi (1981) have developed a more effective tool for the evaluation of CSR based on Carroll's definition (1979) and Maslow's hierarchy of needs (1954). They explained the different needs of different organisations. The hierarchy of organisational staff suggested that organisations, like individuals, have desires that they are satisfied with the implementation of CSR. Freeman (1984) in his book «Strategic Management: A stakeholders Approach» provided a guide developed by the United Nations organisations with different approaches of CSR applied by companies.

Epstein (1987) defines CSR as «Obtaining results from organisational decisions about specific issues to benefit to stakeholders and not only shareholders of the company». It focused on the three concerns: social responsibility, ethics in business, political process. The most exciting concern on Epstein definition is «Social and political process used by the company». It is referring to the use of performances and processes to evaluate the CSR practices.

In the 1990s, several CSR topics were discussed including: social performance, stakeholders, business ethics, and sustainable development. Wood (1991), based on the interactions between companies and society, highlight the categories of responsibility through three-levels. He suggests that the principle of legitimacy is valid at the institutional level. From an organisational point of view, the principle of public accountability suggests that companies are responsible for actions that influence society. Finally, at the individual level, managers need to be constantly aware of the importance of acting with moral behaviour. Wood (1991) has also revived Carroll's (1979) pyramid of responsibilities to include the intricacy of interfering with society and companies. Salmon (1997) argues: «The new companies are often the most powerful institutions in the world, and the extent of social responsibility has broadened to include areas that are once considered a source of government excellence ... More the companies are powerful. More they have responsibility related to the world's well-being».

CSR in the 21st century: more contemporary visions of CSR as an imperative for survival. Another group of researchers has worked to establish the social and financial performance of the companies. While Orlitzky (2005) found that participation in social activities reduces the financial risk, Hopkins (2003) is against; he studied the top 10 British companies and did not confirm such a conclusion. Perrini (2006) suggested that big companies should be based on the stakeholders' theory, while SMBs (Small \& Medium Businesses) should be understood through the social capital theory. Horrigan (2007) described the state of CSR as: «Both the developed and developing countries are reaching the point where they have to decide whether the CSR globalisation is a sporadic social model, a model for the economy, a capitalisation of efficiency, a central vision of ownership, or even a key to the long-term survival of humanity. CSR becomes a vital imperative quickly for a variety of actors in a variety of roles: government, national and international communities». The 
norms push companies to challenge themselves, especially in a competitive context. According to Aggeri et al. (2005), normalisation agencies played a significant role in spreading «CSR good practices». The designed rating systems became a standard reference that participates in the homogenization of CSR practices.

Among the most famous international references, there are: The ISO 26000:2010 standard; Financial Ratings; Professional associations or NGOs or civil society; CSR reporting.

The ISO 26000:2010 contains relevant lines and clarifies the concept of societal responsibility, to help companies and organisations to translate CSR concept into concrete principles and to advertise the best practices. All the types of organisation are concerned, whatever their activity, their size or their location. The ISO 26000 standard includes seven major issues: respect for human rights, working relationships and conditions, fair practices, governance, respect of the environment, consumer issues and community development.

The International Financial Rating assess the performance and give a rating that can be an indicator of performance for investors, based on the information provided by the companies. The leading players operating in Europe are EIRIS (UK), Inrat (Switzerland), MSCI (US), Oekom (Germany), Sustainalytics (Netherlands) and Vigeo (France).

For example, in Morocco, the CSR label is proposed by CGEM, which is the Moroccan Confederation of Companies, it provides an evaluation tool. This disposal translates CSR Commitment to make progress on the management of employees, stakeholders and the community globally.

CSR reporting is a periodical document published by companies to highlight actions and its results in terms of social responsibility. It allows an internal impact by monitoring the impact of their activities on the environment, society and economic ecosystem, and to improve their processes in order to improve results. Second; it allows an external impact by allowing stakeholders better to evaluate the long-term impact of the company activities. However, civil society has an important role to play for the implementation of CSR practices. It is under the pressure of the parties and NGOs that the normative disposals appeared. NGOs characterise the emergence of a genuinely civil society that was progressive as «Balanced Power» between «economics» and «politics» by appropriating a large number of social issues (Queinnec, 2004). This contribution of CSR offers significant influence and give the society a voice to co-regulate the environment (Fransen and Burgoon, 2013). Doh and Guay (2006) highlight the growing role of NGOs and increased participation in national and international debates. The following framework describes the perception of the CSR paradigm according to its decade's evolution (Figure 1).

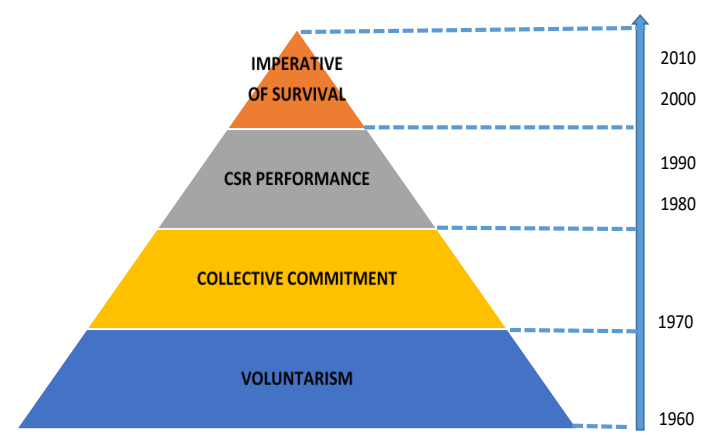

Figure 1. CSR Pyramid adapted to Moroccan context

Source: developed by the author 
Every decade has been marked by authors who have evolved the concept of CSR, from sporadic philanthropy to an imperative of survival of the company. What about the case of a developing country and especially Morocco?

Methodology and research methods. In the empirical research, first, there is a background of Moroccan entrepreneurial context, the problematic and methodology, then the main results of the qualitative study. The Moroccan entrepreneurial context. The Moroccan economy enjoys a great macroeconomic framework. According to the World Bank, in 2017, the country's growth is sustainable (4\%), inflation is controlled (1\%), and the country is politically stable. Also, its geostrategic position at the gateway of Africa and $14 \mathrm{~km}$ only from Europe, gives Morocco the status of a regional hub. Morocco's ambition is to build a modern, productive and competitive economic system. However, by segmenting the Moroccan entrepreneurial panorama, the market structure is atomised, and strongly competed by the grey market. According to the OECD, the Moroccan SMBs in 2017, continues to represent $95 \%$ of the Moroccan companies, $50 \%$ of employment, $20 \%$ of value-added, $30 \%$ of exportations, $40 \%$ of production, and $50 \%$ of the investment. Thus, according to the Moroccan National Agency of SMBs (ANPME) 2017 report, Autoentrepreneurs represent more than 3.5 million units. Very Small Businesses, more than 2 million units. SMBs, more than 35,000 companies. The big companies are only 800 , and their consolidated turnover is about 750 billion Dirhams (Moroccan Devise: $1 \$$ US= 9.55 Dhs). The Pareto law is strongly elucidated.

Morocco is a country with two speeds. Despite the economic development and the progress made in fighting against poverty and social precariousness, thanks to the National Initiative of Human Development (INDH), the Moroccan development model remains confronted to its inclusive limits capacities, particularly in terms of creation of decent jobs and reducing social, spatial and gender disparities. In October 2017, a Royal speech of King Mohammed VI paid particular attention to the quality of growth, its sustainability and its ability to benefit for large segments of the population.

After a detailed review of the CSR evolution and a presentation of the Moroccan context, the problematic remains: «Is CSR having the same perception in developing countries?». To answer this question, a qualitative study was held. The random sample is complicated to apply since the proportion of SMBs is very high, and therefore the results are biased and cannot be generalised. Thus, the choice was about sampling by the convenience of a total of 80 companies surveyed, including 20 Auto-entrepreneurs, 20 Very small Businesses, $20 \mathrm{SMBs}$ and 20 large companies.

The interviews position is "Directors and CEO's» of companies as they have the full vision of company strategy. The interview guide was administrated face to face or by phone. The interview guide is including four themes: Awareness of CSR as a concept, Kind of applied purposes, CSR motivations, CSR brakes, CSR perspectives. The methodology of investigation is to classify the insights of interviews according to the verbatims collected. The qualitative answers were coded and give trends according to the majority positions or feelings. This method helps to analyse in details the given information, to adapt the language to the interview, as CSR as a discipline is sometimes unknown or misunderstood. To go step by step to understand the real insights of the companies.

Results. Business categories will interpret the results according to the pre-established sample. Selfentrepreneurs: the majority of respondents are under 40 years; they know CSR and are mostly technophiles. They are positive about CSR practices and perceive their added value. However, they do not feel at all concerned about the participation of their company which is still at a launch stage and remains vulnerable to unprofitable investments.

Very Small Businesses: The questioned people are from different ages and occupy different professions, including plumber, hairdresser, grocer. The majority do not know the CSR concept and assimilate it to philanthropy.

For these entrepreneurs, investing in social issues depends on the personality of the leader and his predisposition to impact positively the society. It is a proactive approach. 
Small and Medium Businesses: It is essential to distinguish between 2 segments of SMBs; those operating in the local market and those whose activity is oriented into exportation.

SMBs operating in the local market: They recognise CSR, but the significant majority aim to comply exclusively with legal provisions. While they describe CSR as having a moral duty towards stakeholders and society, only $17 \%$ attest that they already did actions outside of legal compliance, such as: distribute Meals to homeless people, renovate public schools, contribute to the construction of public places (gardens, children's park...), encourage diversity in recruitment and integrate people with reduced mobility... However, these actions are voluntary and depend on the commitment of the leaders. Sometimes even these companies practice CSR without knowing it. It was also notified that CSR is mainly practised during the prosperous time, but these actions are the first to cancel in periods of crisis.

SMBs operating in the international market: They represent a minority of total SMBs, they are mainly operating in high value-added sectors like automotive, aeronautics and biochemistry. These SMBs are more familiar with the CSR concept. They practice CSR because it is an obligation to continue operating with international clients committed to responsible purchasing strategy. Thus, they often use an ISO 26000 certification or the label of the General Confederation of Enterprises of Morocco (CGEM).

Large companies: It would be relevant to distinguish between Moroccan companies with local capital and multinational companies established in Morocco.

The big Moroccan companies: For these companies, CSR is perceived as a «license to operate». It is due to the perception of the citizens. According to them: «The Moroccan wealth cannot be used without worrying about the well-being of its community». Among these companies, OCP, Maroc Telecom, Cosumar, Aluminum Morocco, Aksal, Central Danone, Holmarcom ... The OCP (Sherifian Office of Phosphate) is the most representative case since the country is the second-largest producer and the first exporter, it needs a «license to operate». OCP is leading projects such as the creation of smart cities, the construction of schools in poor villages, developing new services. A fascinating example, that highlight the impact of CSR for this category, is about a situation of brands boycott that was occurred in Morocco from June 2018 to September 2018. The boycott concerns three Moroccan brands: «Afriquia» of the «Aksal group», "Sidi Ali» of the "Holmarcom» group and the milk of the "Centrale Laitiere» company, the consumers claimed the no inclusive policy of this brands and their focus on profit only. These companies saw their turnover decreasing by more than $40 \%$ and decide to adapt the offer to the local consumer and to invest more on CSR. For this category of companies, economic performance can be achieved only when it is inclusive. These companies need to focus CSR axes on the community dimension, hence inclusive CSR.

Large international companies: These companies have CSR actions developed in their strategic action plans. They use the same guidelines internationally with adaptation into country context. Thus, Coca Cola distributes free meals during Ramadan month, Procter \& Gamble animates the action «Smile» that consists of intervention for children suffering from Beak of hare. These multinationals understood well that CSR is a condition for survival, whatever the company location. Thus each typology of the company can be classified differently on the framework previously proposed (Figure 2). 


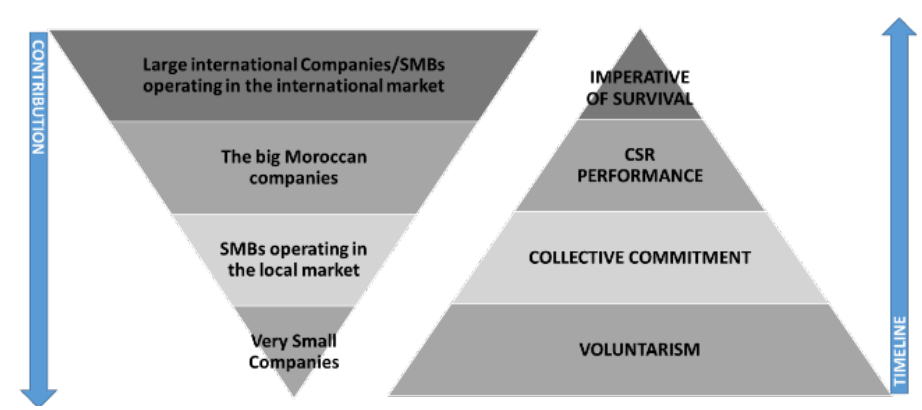

Figure 2. Inverted CSR Pyramid

Source: developed by the author.

This inverted triangle clearly shows that through the evolution of the CSR concept, various segments of companies can be classified. The Moroccan Very Small Businesses still use the same approach developed in the 60s. However, multinationals and SMBs operating in the international market use the most contemporary concepts to get aligned with their partners worldwide. Also, the contribution in terms of allocated budget is more significant for the multinational companies as the CSR is perceived as an imperative of survival.

Conclusions. The CSR is a discipline inspired by the societal reality. Wealth-generating companies have to contribute to the well-being of society. Respect for human rights, good governance, respect of the environment, relationships and working conditions, fair practices, community and local development, and the relationship with the consumer, all these pillars find refuge in CSR. A concept perceived as a panacea for all the social ills. However, CSR is a global concept whose broad outlines are unanimously perceived; that is why local adaptation is crucial. In the Moroccan context, where more than $95 \%$ of companies are SMBs and very small companies, CSR is identified mainly as a social commitment or an act of voluntarism. This situation implies that the CSR actions are more present in the moments of prosperity and decrease, or even are cancelled during periods of crisis. In order to standardise practices, several international standards develop practical tools. Even ISO 26000 certification has included all the components to serve as a model. Investment funds or financial institutions also require a CSR report which guarantees the ethics of business activities and practices. In Morocco, CGEM (General Moroccan Confederation of enterprises) has launched a label to certify companies locally, inspired by the international model. However, after more than a decade from launch, very few Moroccan SMBs are labelled (less than ten). These results confirm that; the more companies are powerful, more they have responsibility related to the world's well-being (Salmon 1997). Also, the concept of CSR in Morocco is global and requires an increased contextualization to be able to include all segments of companies. The international model needs to be adapted to develop for example «Start-Up CSR certification» or «SMB CSR Certification» to encourage the significant majority of companies to improve with small steps, knowing that if the starting step is not encouraged, they will not go into the pipe of certification. The perspective of this research can be an adaptation of CSR certification to the Moroccan context in a pull strategy.

\section{References}

Berle, A. A., \& Means, G. G. C. (1991). The modern corporation and private property. Transaction publishers. [Google Scholar] Bowen, H. R. (1953). Social Responsibilities of the Businessman. Edition: JSTOR.

Doh, J. P. \& Guay, T. R. (2006). Corporate social responsibility, public policy and NGO activism in Europe and the United States: An institutional-stakeholder perspective. Journal of Management studies, 43(1), 47-73. [Google Scholar] [CrossRef] 
Freeman, R. E. (1984). Strategic Management: A stakeholders Approach, p46, Boston, MA: Pitman. Lasted edition. Gond, JP \& Igalens, J. (2008). Corporate Social Responsibility, Edition: PUF editions.

Hack, L., Kenyon, A. J., \& Wood, E. H. (2014). A critical corporate social responsibility (CSR) timeline: How should it be understood now. International Journal of Management Cases, 16(4), 46-55. [Google Scholar]

Hopkins, M. (2003). The business case for CSR: where are we?. International Journal of Business Performance Management, 5(23), 125-140. [Google Scholar] [CrossRef]

Horrigan, B. \& Macquarie J. B. (2007). Century Corporate Social Responsibility. Heinonline.

Johnson, H. (1971). Business in a contemporary society: Framework and issues. Wadsworth Pub. Co.

Kolandarag, S. E., \& Amirkhani, A. (2016). Evaluating the Effect of Corporate Social Responsibility on Social Security Organization Pensioners Satisfaction. International Journal of Humanities and Cultural Studies (IJHCS) ISSN 2356-5926, 3(2), 2040-2059. [Google Scholar]

Malki, T. (2014). Corporate social responsibility: the case of Morocco, Edition Africa East.

Orlitzky, M., Siegel, D. S., \& Waldman, D. A. (2011). Strategic corporate social responsibility and environmental sustainability. Business \& society. [CrossRef]

Perkins, D. H., Radelet, S., \& Lindauer, D. L. (2008). Economie de développement. De Boeck Superieur.

Perrini, F. (2006). SMEs and CSR theory: Evidence and implications from an Italian perspective. Journal of business ethics, 67(3), 305-316. [Google Scholar] [CrossRef]

Rahman, S. (2011). Evaluation of definitions: ten dimensions of corporate social responsibility. World review of Business Research, 1(1), 166-176. [Google Scholar]

Stigler, G. J., \& Friedland, C. (1983). The literature of economics: The case of Berle and Means. The journal of law and economics, 26(2), 237-268. [Google Scholar]

Turcotte, M. F. \& Salmon, A. (2005) The social and environmental responsibility of the company. Edition: Quebec University Press. Tuzzolino, F. \& Armandi, B. R. (1981). A need-hierarchy framework for assessing corporate social responsibility. Academy of management review, 6(1), 21-28. [Google Scholar] [CrossRef]

Walton, C. C. (1967). Corporate Social Responsibility. Wadsworth, Belmont.

Williamson, D., Lynch-Wood, G., \& Ramsay, J. (2006). Drivers of environmental behaviour in manufacturing SMEs and the implications for CSR. Journal of Business Ethics, 67(3), 317-330. [Google Scholar] [CrossRef]

Нада Соуді, професор, Бізнес-школа ISCAE (Марокко).

Управління IT знаннями: поширення принципів корпоративної соціальної відповідальності

Метою статті $є$ аналіз корпоративної соціальна відповідальність (КСВ) як невід'ємної складової забезпечення сталого розвитку. Автором зазначено, що КСВ передбачає врахування соціальних та екологічних питань при формуванні стратегіі розвитку компаній та побудови системи комунікації зі стейкхолдерами. Систематизація літературних джерел з окресленоі тематики дозволила виявити схожість у підходах до визначеннях сутності КСВ відповідно до кожного десятиліття. У статті про ранжовано компанії відповідно до рівня сприйняття та впровадження принципів КСВ, що дозволило обгрунтувати наявні розриви у сприйнятті КСВ. Автором виділено наявність десятирічного розриву та визначено, що на перших етапах розвитку теорії корпоративного управління, КСВ розглядався як добровільний інструмент корпоративного управління. У статті висунуто наступні гіпотези: рівень сприйняття КСВ однаковий серед підприємств у країнах, що розвиваються; за умови виявлення розривів, період їх тривалості для компаній різних секторів економіки - різний. Детерміновану вибірку сформовано на основі результатів опитування працівників 80 компаній щодо ї рівня поінформованості про цілі та принципи КСВ, мотивації їі впровадження, а також бар'єрів та переваг КСВ. Враховуючи отримані результати сформовано перевернутий трикутник знань притаманний для підприємств Марокко. Визначено, що працівники малих та середніх підприємств (питома вага яких складає - 95\% у Марокканській економіці) сприймають КСВ як таку, що існувала у 70-х роках ХХ ст. У свою чергу, працівники великих компанії та корпорацій (питома вага, яких складає - 5\%) КСВ сприймається як імператив забезпечення конкурентоздатності на міжнародному ринку. При цьому встановлено, що малі та середні підприємства та великі компаніі по-різному сприймають КСВ, однак, мають аналогічне сприйняття КСВ у випадку зростання бізнесу або виходу на міжнародний ринок. У статті доведено, що впровадження системи управління знаннями в компаніях з використанням інформаційних технологій забезпечить підвищення рівня поінформованості про принципи та цілі КСВ, що тим самим сформує передумови для поширення КСВ серед компаній. Отримані результати дослідження можуть бути використані менеджментом компаній при формуванні стратегій виходу на міжнародний ринок.

Ключові слова: корпоративна соціальна відповідальність, країни, що розвиваються, еволюція корпоративної соціальної відповідальності, управління IT знаннями.

Manuscript received: 09.12.2019.

(c) The author(s) 2020. This article is published with open access at Sumy State University. 